\title{
Linking Hydraulic Conductivity to Anatomy in Plants that Vary in Specific Root Length
}

\author{
Bingru Huang ${ }^{1}$ \\ Department of Horticulture, Forestry, and Recreation Resources, Kansas State University, Manhattan, \\ KS 66506-5506
}

\author{
David M. Eissenstat \\ Department of Horticulture, The Pennsylvania State University, University Park, PA 16802
}

AdDitional INDEX words. Citrus, cortex, exodermis, root diameter, xylem vessels, water uptake

\begin{abstract}
In Citrus L. sp., specific root length of whole root systems has been correlated positively with root hydraulic conductivity, but there is little mechanistic understanding of the causes for this association. The hydraulic conductivity of individual roots in relation to root anatomical characteristics in seedlings of three citrus rootstocks [sour orange (SO) (Citrus aurantium L.), trifoliate orange (TO) (Poncirus trifoliate (L.) Raf.), and Swingle citrumelo (SC) (C. paradisi Macf. $x P$. trifoliata)] that vary widely in specific root length (SRL) was measured. Among fibrous roots, first-order and secondorder laterals were examined. Relative differences among rootstocks in the overall hydraulic conductivity $\left(L_{P}\right)$ and radial conductivity $\left(L_{R}\right)$ for individual 1-month-old and 6-month-old second- and first-order roots generally were consistent with hydraulic conductivity determined previously for entire root systems. There were no significant differences in axial conductance per unit pressure $\left(K_{h}\right)$ in either first- or second-order roots among the rootstocks. This was consistent with the similarity in number and diameter of xylem vessels. One-month-old second-order roots had no suberized exodermis but varied in cortical radius. Six-month-old second-order roots of TO, however, had more nonsuberized cells (passage cells) in the exodermis than roots of SC and SO, although the cortical radius of SC and SO roots were not different. Compared to 6-month-old second-order roots, 1-month-old second-order roots had much higher $L_{P}$ and $L_{R}$ but lower $K_{h}$. Differences in overall root hydraulic conductivity among the citrus rootstocks were mainly related to structural differences in the radial pathway for water movement, suggesting that radial hydraulic conductivity was the primary determining factor of water uptake in citrus rootstocks.
\end{abstract}

Water flow from the soil to the root xylem is determined by hydraulic conductivities of three components of the root-soil pathway: the soil, the root-soil interface, and the root (reviewed by Passioura, 1988). Under soil drying conditions, the soil rather than the root is a major limiting factor for water uptake (Nobel and Cui, 1992). Rieger and Duemmel (1992) reported that hydraulic conductivities of entire root systems were similar in drying soil in several Prunus L. sp., even though they differed in drought resistance. When soil moisture is readily available, however, root hydraulic conductivity can represent two-thirds of the limitations on water movement within the soil-plant system (Nobel and Cui, 1992; Passioura, 1988). Therefore, differences in root hydraulic conductivity in wet soils could result in differences in water transport to shoots that could influence leaf water status, and in turn, plant growth and physiological responses (Passioura, 1988).

Hydraulic conductivity of whole root systems has been reported to be correlated positively with shoot growth rate in several citrus rootstocks (Syvertsen, 1981). Relatively vigorous rootstocks [e.g., rough lemon (Citrus jambhiri) and Carrizo citrange] tend to have higher conductivities, stomatal conductance, and transpiration rates than the less vigorous rootstocks [Cleopatra mandarin (Citrus reshni Hort. ex Tan) and sour orange (C. aurantiacum)] (Syvertsen and Graham, 1985). Root hydraulic conductivity for entire root systems also is higher in citrus rootstock species that have higher specific root lengths (SRLs) (Eissenstat, 1992, 1997; Graham and Syvertsen, 1985). High

Received for publication 25 May 1999. Accepted for publication 29 Nov. 1999. Kansas Agricultural Experiment Station contribution 99-279-J. We thank J.P. Syvertsen and Dian Achor for helpful reviews of this manuscript. The cost of publishing this paper was defrayed in part by the payment of page charges. Under postal regulations, this paper therefore must be hereby marked advertisement solely to indicate this fact.

${ }^{1}$ Corresponding author. hydraulic conductivity of roots with large SRL may be attributed to a greater radial hydraulic conductivity of individual roots with smaller diameters. Roots of small diameter may have a shorter radial path for water movement from the root surface into the xylem than large-diameter roots. Variation in root hydraulic conductivity among different citrus rootstocks could also be linked to specific root anatomical features such as suberization and thickness of the secondary wall of the exodermis and endodermis (Huang and Nobel, 1994). Rieger and Litvin (1999) have measured root-system hydraulic conductivity of whole, intact plants, and root anatomical features of two woody and three herbaceous species. They found that root-system hydraulic conductivity is inversely related to root cortical thickness and the presence of a suberized exodermis.

The objectives of this study were to 1) determine overall hydraulic conductivity, radial and axial hydraulic conductivity of different types and ages of fibrous roots for three citrus rootstocks [sour orange (SO), trifoliate orange (TO) (Poncirus trifoliate (L.) Raf.), and Swingle citrumelo (SC) (C. paradisi Macf. $x P$. trifoliata)] that vary in SRL and root anatomical features; and 2) determine anatomical features that are correlated with radial and axial hydraulic conductivity of individual roots in the three rootstocks. The rootstocks, SO and SC, have similar SRLs and seedling root-system hydraulic conductivity, whereas TO has a much higher SRL and root system hydraulic conductivity (Eissenstat 1997).

\section{Materials and Methods}

Plant materials and growth Conditions. Rootstocks were grown in sand in 2-L pots for 6 months after seedling emergence in a growth chamber with average day/night temperatures of 30/ $25^{\circ} \mathrm{C}$, a photosynthetic photon flux (PPF) of $600 \mu \mathrm{mol} \cdot \mathrm{m}^{-2} \cdot \mathrm{s}^{-1}$ at 
the canopy level, and a $12 \mathrm{~h}$ photoperiod provided by flourescent lamps and incandescent bulbs. Plants were fertilized weekly with full-strength Hoagland's solution (Hoagland and Arnon, 1950) and watered every other day with deionized water.

Hydraulic CONDUCTIVITY MEASUREMENTS. Overall root hydraulic conductivity $\left(\mathrm{L}_{\mathrm{p}}\right)$, radial conductivity $\left(\mathrm{L}_{\mathrm{R}}\right)$, and axial conductance per unit pressure gradient $\left(\mathrm{K}_{\mathrm{h}}\right)$ were determined on three types of individual fibrous roots in each rootstock: a) distal 5-cm root segments from 1-month-old second-order lateral roots (roots bearing first-order lateral roots) of various diameters; b) basal 5-cm root segments from 6-month-old second-order lateral roots of similar diameters; and c) entire first-order lateral roots (roots having a root tip) of various diameters associated with the 6-month-old second-order roots. Root age was estimated by tagging roots with different color strings when roots were $\approx 1 \mathrm{~cm}$ long. After tagging, roots were returned to their original position in the soil and allowed to grow for 1 to 6 months before the measurements.

Hydraulic conductivities of three types of individual fibrous roots $\left(\mathrm{L}_{\mathrm{p}}\right)$ as described above were measured with the tensioninduced flow technique, in which water flow is induced through excised roots by application of negative pressures (Huang and Nobel, 1992; Nobel and Sanderson, 1984). About $5 \mathrm{~mm}$ of the stele at the proximal end of the root was exposed by dissecting away cortical tissue. The exposed stele was trimmed under water and inserted through Tygon tubing (10 $\mathrm{mm}$ in length, internal diameter of $1 \mathrm{~mm}$ ) and into an attached glass capillary $(100 \mathrm{~mm}$ in length, internal diameter of $0.5 \mathrm{~mm}$ ) that was half-filled with distilled water. The tubing was gently compressed around the stele using brass and silicone washers inside a compression fitting (Lopez and Nobel, 1991).

For $\mathrm{L}_{\mathrm{P}}$ measurements of second-order lateral roots, an entire root or root segment was suspended in aerated 0.1 strength Hoagland's solution (Hoagland and Arnon, 1950). Water flow through the root was induced by applying a partial vacuum, whose pressure was measured with a pressure transducer (KaneMay Ltd., Welwyn Garden City, U.K.) connected to the open end of the capillary tube. To measure $L_{P}$ of first-order lateral roots attached to second-order lateral roots, the proximal end of the second-order root was inserted into the capillary where a 20 to 40 $\mathrm{kPa}$ vacuum pressure was applied, with the entire first-order lateral root submerged in nutrient solution. The flow rate was determined by monitoring the progress of the meniscus in the capillary with a traveling microscope capable of resolving 0.01 $\mathrm{mm}$. When the volumetric flow rate $\left(\mathrm{Q}_{\mathrm{v}}, \mathrm{m}^{3} \cdot \mathrm{s}^{-1}\right)$ became constant at a given pressure $(\mathrm{P}, \mathrm{MPa}), \mathrm{L}_{\mathrm{P}}$ was calculated as follows (Nobel et al., 1990):

$\mathrm{L}_{\mathrm{P}}=\left(\Delta \mathrm{Q}_{\mathrm{v}} / \Delta \mathrm{P}\right)(1 / \mathrm{A})$

where $\mathrm{A}$ is the root surface area $\left(\mathrm{m}^{2}\right)$.

To measure $\mathrm{K}_{\mathrm{h}}$, the distal end of the segment was recut under distilled water and $\approx 1 \mathrm{~mm}$ at the distal end was immersed in 10 $\mathrm{mol} \cdot \mathrm{m}^{-3}$ oxalic acid in filtered, degassed, distilled water (to reduce blockage of the vessels; Sperry et al., 1988). After applying a partial vacuum to the capillary tube on the proximal end, $\mathrm{Q}_{\mathrm{v}}$ was measured as for $L_{P}$ and used to calculate $K_{h}$ :

$\mathrm{K}_{\mathrm{h}}=\mathrm{Q}_{\mathrm{v}} /(\Delta \mathrm{P} / l)$

where $l$ is the length $(\mathrm{m})$ of the root across which $\Delta \mathrm{P}$ was applied.

After $\mathrm{L}_{\mathrm{P}}$ and $\mathrm{K}_{\mathrm{h}}$ were determined, $\mathrm{L}_{\mathrm{R}}\left(\mathrm{m}^{3} \cdot \mathrm{m}^{-2} \cdot \mathrm{s}^{-1} \cdot \mathrm{MPa}^{-1}\right)$, averaged over the root, was calculated by incorporating $\mathrm{L}_{\mathrm{P}}, \mathrm{K}_{\mathrm{h}}$, the length, and the radius $\left(\mathrm{r}_{\text {root }}\right)$ of root segments into the model of
Landsberg and Fowkes (1978): $\mathrm{L}_{\mathrm{R}}=\left(L_{\mathrm{p}} \alpha l\right) /(\tanh \alpha l)$, where $\alpha$ equals $\left(2 \pi r_{\text {root }} L_{R} / K_{h}\right)^{1 / 2}$

Morphological AND ANATOMiCAL FEATURES. Root diameter of individual roots was measured with a micrometer on a light microscope. Freehand sections were cut with a razor blade at the midlength of the root segments after measurements of $L_{P}, L_{R}$, and $\mathrm{K}_{\mathrm{h}}$. The sections were stained with toluidine blue $\mathrm{O}$ for determination of cortical thickness and number and diameter of xylem vessels or with Sudan III and IV for identifying suberization of the exodermis.

Satistical ANALYsis. Data were collected from five plants of each rootstock and analyzed using analysis of variance procedures of the SAS (SAS Institute Inc., Cary, N.C.). Differences among rootstock means were separated least significance difference (LSD) procedures at $P<0.05$.

\section{Results}

For individual first-order lateral roots, both overall hydraulic conductivity $\left(\mathrm{L}_{\mathrm{p}}\right)$ and radial conductivity $\left(\mathrm{L}_{\mathrm{R}}\right)$ of TO were signifi-

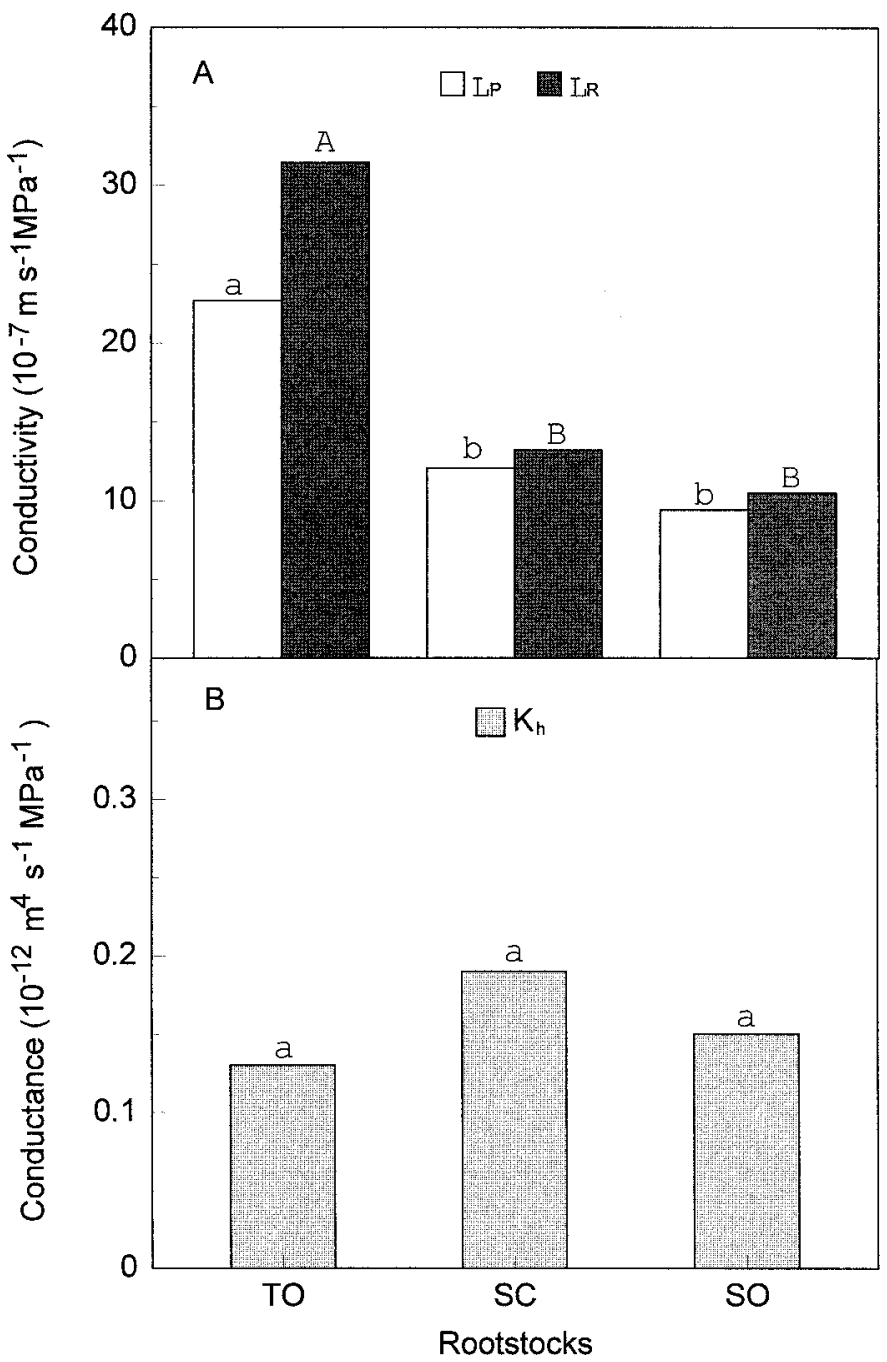

Fig. 1. (A) Hydraulic conductivity $\left(\mathrm{L}_{\mathrm{P}}\right)$ and radial conductivity $\left(\mathrm{L}_{\mathrm{R}}\right)$, and $(\mathbf{B})$ axial conductance per unit pressure gradient $\left(\mathrm{K}_{\mathrm{h}}\right)$ of first-order lateral roots in three citrus rootstocks, trifoliate orange (TO), Swingle citrumelo (SC), and sour orange (SO). Data were means of five individual roots from each of five plants in each rootstock. Columns marked with the same lowercase or uppercase letters are not significantly different based on an LSD test $(P=0.05)$. 
Table 1. Anatomical features of first-order lateral roots of three citrus rootstocks, trifoliate orange (TO), Swingle citrumelo (SC), and sour orange (SO), measured on cross sections at the midlength of individual roots. Data are means of five individual roots from each of five plants in each rootstock.

\begin{tabular}{|c|c|c|c|c|c|}
\hline \multirow[b]{2}{*}{ Rootstock } & \multirow{2}{*}{$\begin{array}{l}\text { Root } \\
\text { diam } \\
(\mu \mathrm{m})\end{array}$} & \multirow{2}{*}{$\begin{array}{c}\text { Cortical } \\
\text { thickness } \\
(\mu \mathrm{m})\end{array}$} & \multirow{2}{*}{$\begin{array}{c}\text { Nonsuberized } \\
\text { exodermal } \\
\text { cells } \\
(\%)\end{array}$} & \multicolumn{2}{|c|}{$\begin{array}{l}\text { Xylem } \\
\text { vessels }\end{array}$} \\
\hline & & & & No. & $\begin{array}{l}\text { Diam } \\
(\mu \mathrm{m})\end{array}$ \\
\hline $\mathrm{TO}$ & $344 b^{2}$ & $84 \mathrm{~b}$ & $12.4 \mathrm{a}$ & $9 a b$ & $4.6 \mathrm{a}$ \\
\hline $\mathrm{SC}$ & $411 \mathrm{a}$ & $115 \mathrm{a}$ & $7.4 \mathrm{~b}$ & $11 \mathrm{a}$ & $6.0 \mathrm{a}$ \\
\hline SO & $445 \mathrm{a}$ & $120 \mathrm{a}$ & $8.6 \mathrm{~b}$ & $7 \mathrm{~b}$ & $5.2 \mathrm{a}$ \\
\hline
\end{tabular}

${ }^{\mathrm{z}}$ Mean separation within columns by LSD at $P \leq 0.05$.

cantly higher than those for SC and SO (Fig. 1A), but axial conductivity $\left(\mathrm{K}_{\mathrm{h}}\right)$ of the three rootstocks, however, were not significantly different (Fig. 1B). The larger $\mathrm{L}_{P}$ and $\mathrm{L}_{R}$ for $\mathrm{TO}$ than $\mathrm{SC}$ and SO, was related to the shorter radial pathway and greater percentage of nonsuberized cells (passage cells) in the exodermis in TO (Table 1). First-order lateral roots of TO were significantly

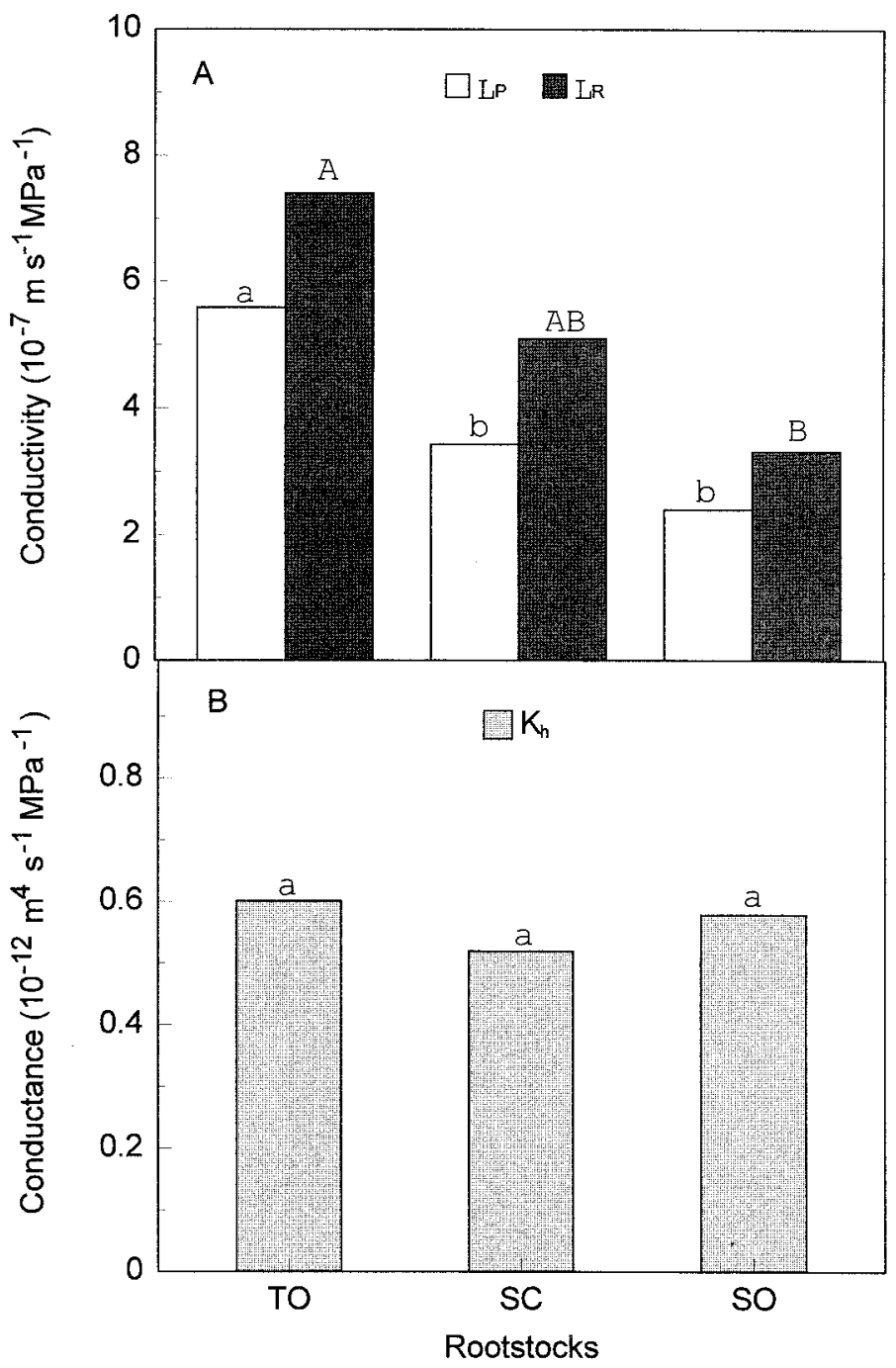

Fig. 2. (A) Hydraulic conductivity $\left(\mathrm{L}_{\mathrm{p}}\right)$, radial conductivity $\left(\mathrm{L}_{\mathrm{R}}\right)$, and $(\mathbf{B})$ axial conductance per unit pressure gradient $\left(\mathrm{K}_{\mathrm{h}}\right)$ of 1-month-old second-order lateral roots in three citrus rootstocks, trifoliate orange (TO), Swingle citrumelo (SC), sour orange (SO). Data were means of five individual roots from each of five plants in each rootstock. Columns marked with the same lowercase or uppercase letters were not significantly different based on an LSD test $(P=0.05)$. thinner than those of SC and SO (Table 1). First-order lateral roots of TO also had a thinner cortical tissue and a significantly higher proportion of nonsuberized cells in the exodermis in roots of TO than those of SC and SO . Axial hydraulic conductance $\left(\mathrm{K}_{\mathrm{h}}\right)$ was quite similar among rootstocks (Fig 1.), which probably reflects the similarity in xylem vessel diameter (Table 1).

For 1-month-old second-order lateral roots, $\mathrm{L}_{\mathrm{p}}$ values for SC and $\mathrm{SO}$ were similar, but both had significantly lower $\mathrm{L}_{\mathrm{P}}$ than that of TO (Fig. 2A). $\mathrm{L}_{\mathrm{R}}$ was highest for TO, intermediate for SC, and lowest for SO. The rootstock difference in $\mathrm{L}_{R}$ of 1-month-old second-order lateral roots were reflected in the variation in root diameter and cortical radius. Roots were thinnest for TO, intermediate for SC, and thickest for SO (Table 2). TO also had a smaller cortical radius than $\mathrm{SC}$ and $\mathrm{SO}$. Similar to first-order roots, $\mathrm{K}_{\mathrm{h}}$ of the 1-month-old second-order lateral roots was not significantly different among rootstocks (Fig. 2B). Similarly, there were no differences in number and diameter of xylem vessels between rootstocks (Table 2).

For 6-month-old second-order lateral roots, both $\mathrm{L}_{\mathrm{p}}$ and $\mathrm{L}_{\mathrm{R}}$ of TO were significantly higher than those for SC and SO (Fig. 3A). Root diameter and cortical radius were not significantly different among rootstocks (Table 3). TO had more passage cells in the exodermis than either $\mathrm{SC}$ or $\mathrm{SO}$. These results indicated that the difference in $\mathrm{L}_{\mathrm{p}}$ and $\mathrm{L}_{\mathrm{R}}$ of 6-month-old second-order lateral roots among the three rootstocks was related mainly to the greater percent of passage cells. Although the diameters of xylem vessels were not different among rootstocks, $\mathrm{K}_{\mathrm{h}}$ was highest in TO, intermediate in $\mathrm{SO}$ and lowest in $\mathrm{SC}$, which was consistent with the results for the number of xylem vessels (Fig. 3B, Table 3).

For all the three rootstocks, $L_{p}$ and $L_{R}$ of 1-month-old secondorder lateral roots (Fig. 2A) were significantly larger than those of 6-month-old roots (Fig. 3A). However, $\mathrm{K}_{\mathrm{h}}$ of 1-month-old second-order lateral roots (Fig. 2B) was much lower than that of 6-month-old roots (Fig. 3B).

Table 2. Anatomical features of 1-month-old second-order lateral roots of three citrus rootstocks, trifoliate orange (TO), swingle citrumelo (SC), sour orange (SO), measured on cross sections at the midlength of individual roots. Data are means of five individual roots from each of five plants in each rootstock.

\begin{tabular}{llclr}
\hline \hline & & & \multicolumn{2}{c}{$\begin{array}{c}\text { Xylem } \\
\text { vessels }\end{array}$} \\
\cline { 3 - 5 } & Root & Cortical & & $\begin{array}{r}\text { Diam } \\
\text { diam }\end{array}$ \\
thickness & & & \\
Rootstock & $(\mu \mathrm{m})$ & $(\mu \mathrm{m})$ & $15 \mathrm{a}$ & $9.4 \mathrm{a}$ \\
\hline TO & $620 \mathrm{c}^{\mathrm{z}}$ & $227 \mathrm{~b}$ & $13 \mathrm{a}$ & $8.2 \mathrm{a}$ \\
SC & $754 \mathrm{~b}$ & $301 \mathrm{a}$ & $16 \mathrm{a}$ & $10.1 \mathrm{a}$ \\
SO & $871 \mathrm{a}$ & $348 \mathrm{a}$ &
\end{tabular}

${ }^{\mathrm{z}}$ Mean separation within columns by LSD at $P \leq 0.05$. 


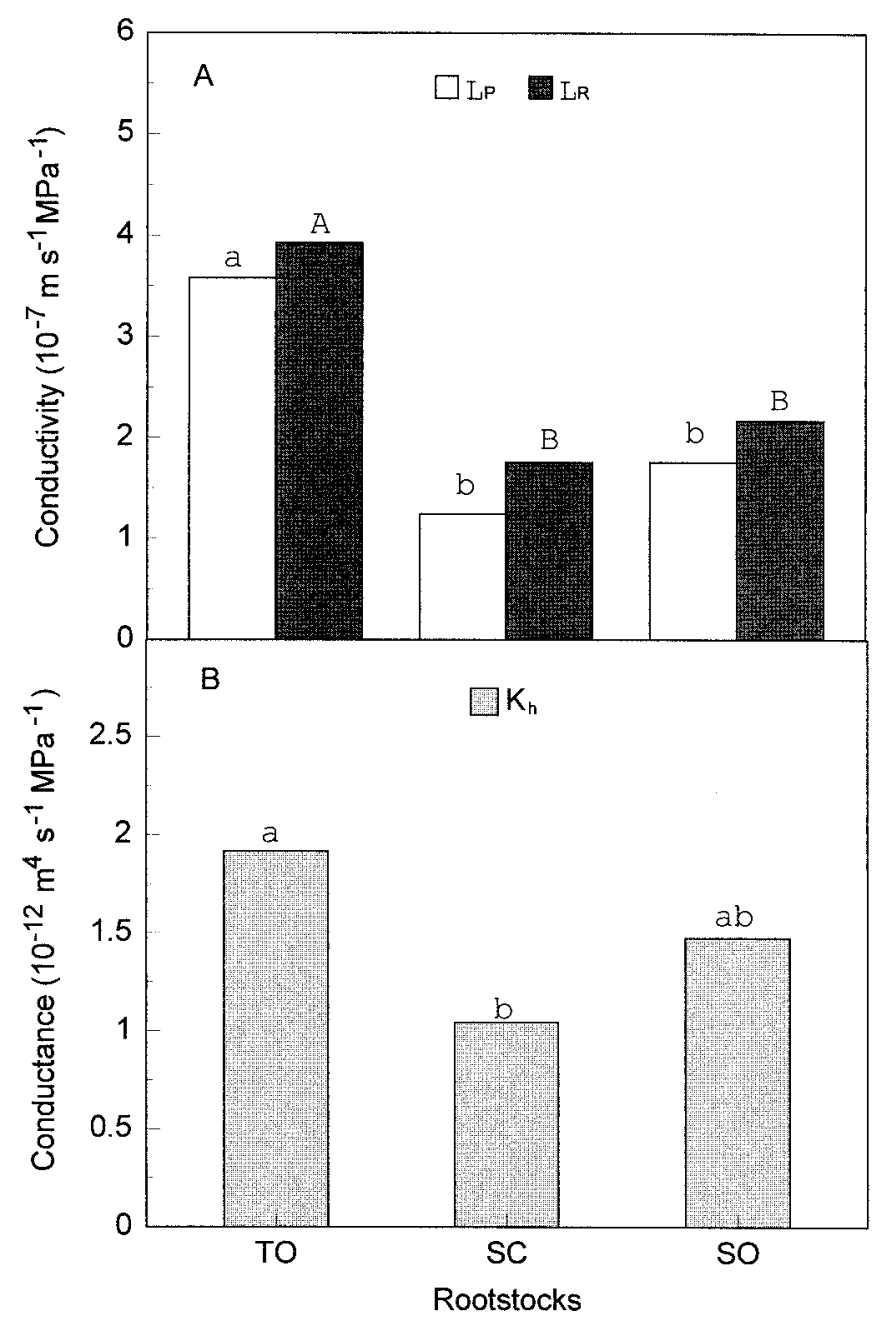

Fig. 3. (A) Hydraulic conductivity $\left(\mathrm{L}_{\mathrm{P}}\right)$ and radial conductivity $\left(\mathrm{L}_{\mathrm{R}}\right)$, and $(\mathbf{B})$ axial conductance per unit pressure gradient $\left(\mathrm{K}_{\mathrm{h}}\right)$ of 6-month-old second-order lateral roots in three citrus rootstocks, trifoliate orange (TO), Swingle citrumelo (SC), sour orange (SO). Data were means of five individual roots from each of five plants in each rootstock. Columns marked with the same lowercase or uppercase letters were not significantly different based on an LSD test $(P=0.05)$.

\section{Discussion}

Root $\mathrm{L}_{\mathrm{p}}$ and $\mathrm{L}_{\mathrm{R}}$ decreased while $\mathrm{K}_{\mathrm{h}}$ increased with root age in all three rootstocks. These results were consistent with observations in other species (Huang and Nobel, 1992, 1993; Jones et al., 1988; North and Nobel, 1991; Radin and Eidenbock, 1984; Sanderson, 1983). Such changes often correspond to developmental changes in suberization of cell layers along the radial pathway and to the maturation of xylem vessels (Drew, 1979, 1987; Huang and Nobel, 1992, 1993; Moreshetet al., 1996). Increases in $\mathrm{K}_{\mathrm{h}}$ as roots age in Agave deserti Engelm., coincides with increases in the number of xylem vessels that are functional in water uptake and transport, since cross walls of xylem vessels disappear as roots become mature(Huang and Nobel, 1992).

As water from the surrounding soil enters a root, it moves radially through the exodermis and cortical tissues external to the stele before reaching the xylem vessels. Exodermis and cortical tissues can impose considerable resistance to water movement in the radial pathway (Moreshet et al., 1996). The exodermis can become suberized as roots age or under environmental stresses such as drought stress which reduces permeability to water (Huang and Nobel, 1994; Peterson and Lefcourt, 1990; Peterson et al., 1993). Therefore, roots with a large cortical radius and well-suberized exodermis could have a low $\mathrm{L}_{\mathrm{R}}$. Rieger and Litivin (1999)reported that the low hydraulic conductivity of intact root systems is related to thick root cortex and the presence of a suberized exodermis.

Previous research (reviewed by Eissenstat, 1997) of detopped seedlings indicates that $\mathrm{SO}$ and $\mathrm{SC}$ have quite similar wholeroot-system hydraulic conductivity of $\approx 5$ to $7 \mu \mathrm{g} \cdot \mathrm{m}^{-1} \cdot \mathrm{s}^{-1} \cdot \mathrm{MPa}^{-1}$ whereas TO has a hydraulic conductivity 3 to 4 times higher $(\approx 20$ $\left.\mu \mathrm{g} \cdot \mathrm{m}^{-1} \cdot \mathrm{s}^{-1} \cdot \mathrm{MPa}^{-1}\right)$. Results from hydraulic conductivity of individual roots in this study are consistent with differences in wholeroot-system conductivity among rootstocks. All three rootstocks had similar $K_{h}$ and diameters of xylem vessels. Results of the present study indicated that the primary cause for the differences in $\mathrm{L}_{\mathrm{p}}$ was due largely to differences in $\mathrm{L}_{\mathrm{R}}$ and only to a minor extent in $\mathrm{K}_{\mathrm{h}}$. The morphological and anatomical characteristics correlated to these differences in hydraulic conductivity are thinner roots with a shorter radial path length (Rieger and Litvin, 1999), thinner outer tangential exodermal walls (Eissenstat and Achor, 1999), and more passage cells in the exodermis (this study).

The relative importance of the two components of $\mathrm{L}_{\mathrm{P}}, \mathrm{L}_{\mathrm{R}}$, and $\mathrm{K}_{\mathrm{h}}$, varies with plant species and with the developmental stage of the root (Huang and Nobel, 1994). For both first and second-order lateral roots of citrus rootstocks, changes in $\mathrm{L}_{\mathrm{P}}$ were consistent with that in $L_{R}$, which indicated that $L_{R}$ was mainly responsible for changes in $\mathrm{L}_{P}$ in citrus. Radial conductivity is the major limitation for water uptake in cotton (Gossypium hirsutum L.) (Taylor and Klepper, 1975) and corn (Zea mays L.), except at the root tip (Frensch and Steudle, 1989; Huang and Nobel, 1992). In contrast, $\mathrm{K}_{\mathrm{h}}$ has been found to limit water movement in seminal roots of wheat (Triticum aestivum L.) (Passioura, 1980), especially at a distance $>1 \mathrm{~m}$ from the base. These $\mathrm{K}_{\mathrm{h}}$ limitations may not be crucial for dicotyledonous crops with secondary xylem vessels (Rendig and Taylor, 1989) but $\mathrm{K}_{\mathrm{h}}$ may be important distally in the fully mature xylem (Oosterhuis and Wullschleger, 1987; North and Nobel, 1992).

Table 3. Anatomical features of 6-month-old second-order lateral roots of three citrus rootstocks, trifoliate orange (TO), swingle citrumelo (SC), and sour orange (SO) measured on cross sections at the midlength of individual roots. Data are means of five individual roots from each of five plants in each rootstock.

\begin{tabular}{|c|c|c|c|c|c|}
\hline \multirow[b]{2}{*}{ Rootstock } & \multirow{2}{*}{$\begin{array}{l}\text { Root } \\
\text { diam } \\
(\mu \mathrm{m})\end{array}$} & \multirow{2}{*}{$\begin{array}{c}\text { Cortical } \\
\text { thickness } \\
(\mu \mathrm{m})\end{array}$} & \multirow{2}{*}{$\begin{array}{l}\text { Nonsuberized } \\
\text { exodermal } \\
\text { cells } \\
(\%)\end{array}$} & \multicolumn{2}{|c|}{$\begin{array}{l}\text { Xylem } \\
\text { vessels }\end{array}$} \\
\hline & & & & No. & $\begin{array}{l}\text { Diam } \\
(\mu \mathrm{m})\end{array}$ \\
\hline$\overline{\mathrm{TO}}$ & $585 \mathrm{a}^{\mathrm{z}}$ & $180 \mathrm{a}$ & $9.3 \mathrm{a}$ & $35 \mathrm{a}$ & $11.2 \mathrm{a}$ \\
\hline $\mathrm{SC}$ & $592 \mathrm{a}$ & $184 \mathrm{a}$ & $4.1 \mathrm{~b}$ & $28 \mathrm{~b}$ & $12.0 \mathrm{a}$ \\
\hline SO & $605 a$ & $192 \mathrm{a}$ & $3.2 \mathrm{~b}$ & $33 a b$ & $12.5 \mathrm{a}$ \\
\hline
\end{tabular}

${ }^{\mathrm{z}}$ Mean separation within columns by LSD at $P \leq 0.05$. 
In summary, the fineness of individual roots was related positively to radial hydraulic conductivity, supporting previous work on whole root systems. Variations in hydraulic conductivity of individual roots among citrus rootstocks were due mainly to differences in radial hydraulic conductivity. Higher $L_{p}$ and $L_{R}$ for citrus rootstocks with higher SRL and smaller root diameter were associated with a less prominent exodermis (thinner secondary walls, greater percentage of passage cells), and a short radial pathway.

\section{Literature Cited}

Drew, M.C. 1979. Properties of roots which influence rates of absorption, p. 21-38. In: J.L. Harley and R.S. Russell (eds.). The Soil-root interface. Academic Press, London.

Drew, M.C. 1987. Function of root tissues in nutrient and water transport, p. 53-70. In: P.J. Gregory, J.V. Lake, and D.A. Rose (eds.). Root development and function. Soc. for Experimental Biol. Seminar Ser. 30. Cambridge Univ. Press, Cambridge, U.K.

Eissenstat, D.M. 1992. Costs and benefits of constructing roots of small diameter. J. Plant Nutr. 15:763-782.

Eissenstat, D.M. 1997. Trade-offs in root form and function, p. 173-199. In: L.E. Jackson (ed.). Ecology in agriculture. Academic Press, San Diego.

Eissenstat, D.M and D.S. Achor. 1999. Anatomical characteristics of roots for citrus rootstocks that vary in specific root length. New Phytol. (in press).

Frensch, J. and E. Steudle. 1989. Axial and radial hydraulic resistance in roots of maize (Zea mays L.). Plant Physiol. 91:719-726.

Graham, J.H. and J.P. Syvertsen. 1985. Host determinants of mycorrhizal dependency of citrus rootstock seedlings. New Phytol. 101:667676.

Hoagland, D.R. and D.I. Arnon. 1950. The water-culture method for growing plants without soil. Calif. Agr. Expt. Sta. Circ. 347:1-32.

Huang, B. and P.S. Nobel. 1992. Hydraulic conductivity and anatomy for lateral roots of Agave deserti during root growth and drought-induced abscission. J. Expt. Bot. 43:1441-1449.

Huang, B. and P.S. Nobel. 1993. Hydraulic conductivity and anatomy along lateral roots of cacti: Changes with soil water status. New Phytol. 123:499-507.

Huang, B. and P.S. Nobel. 1994. Root hydraulic conductivity and its components, with emphasis on desert succulents. Agron. J. 86:767774.

Jones, H., R.A. Leigh, R.G. Wyn Jones, and A.D. Tomos. 1988. The integration of whole root and cellular hydraulic conductivities in cereal roots. Planta 174:1-7.

Landsberg, J.J. and N.D. Fowkes. 1978. Water movement through plant roots. Ann. Bot. 42:493-508.

Lopez, F. and P.S. Nobel. 1991. Root hydraulic conductivity of two cactus species in relation to root age, temperatures, and soil water status. J. Expt. Bot. 42:143-149

Moreshet, S., B. Huang, and H.G. Huck. 1996. Water permeability of roots, p. 659-678. In: Y. Waisel, A. Eshel, and U. Kafkafi (eds.). Plant roots: The hidden half. Marcel Dekker, New York.

Nobel, P.S. and M. Cui. 1992. Hydraulic conductances of the soil, the root-soil air gap, and the root: Changes for desert succulents in drying soil. J. Expt. Bot. 43:319-326.

Nobel, P.S. and J. Sanderson. 1984. Rectifier-like activities of roots of two desert succulents. J. Expt. Bot. 35:727-737.

Nobel, P.S., P.J. Schulte, and G.B. North. 1990. Water influx characteristics and hydraulic conductivity for roots of Agave deserti Engelm. J. Exp. Bot. 41:409-415.

North, G.B. and P.S. Nobel. 1991. Changes in hydraulic conductivity and anatomy caused by drying and rewetting roots of Agave deserti (Agavaceae). Amer. J. Bot. 78:906-915.

North, G.B. and P.S. Nobel. 1992. Drought-induced changes in hydraulic conductivity and structure for roots of Ferocactus acanthodes and Opuntia ficus-indica. New Phytol. 120:9-19.

Oosterhuis, D.M. and S.D. Wullschleger. 1987. Water flow through cotton roots in relation to xylem anatomy. J. Expt. Bot. 38:1866-1874.

Passioura, J.B. 1980. The transport of water from soil to shoot in wheat seedlings. J. Expt. Bot. 31:333-345.

Passioura, J.B. 1988. Water transport in and to roots. Annu. Rev. Plant Physiol. Plant Mol. Biol. 39:245-265.

Peterson, C.A. and B.E. Lefcourt. 1990. Development of endomermal Casparian bands and xylem in lateral roots of broad bean. Can. J. Bot. 68:2729-2735.

Peterson, C.A., M. Murrmann, and E. Steudle. 1993. Location of the major barriers to water and ion movement in young roots of Zea mays L. Planta 190:127-136.

Radin, J.W. and M.P. Eidenbock. 1984. Hydraulic conductivity as a factor limiting leaf expansion of phosphorus deficient cotton plants. Plant Physiol. 75:372-377.

Rendig, V.V. and H.M. Taylor. 1989. Principles of soil-plant interrelationships. McGraw-Hill, New York.

Rieger, M. and M.J. Duemmel. 1992. Comparison of drought resistance among Prunus species from divergent habitats. Tree Physiol. 11:369380.

Rieger, M. and P. Litvin. 1999. Root system hydraulic conductivity in species with contrasting root anatomy. J. Expt. Bot. 50:201-209.

Sanderson, J. 1983. Water uptake by different regions of the barley root: Pathways of radial flow in relation to the development of the endodermis. J. Expt. Bot. 34:240-253.

Sperry, J.S., J.R. Donnelly, and M.T. Tyree. 1988. Seasonal occurrence of xylem embolism in sugar maple (Acer saccharum). Amer. J. Bot. 75:1212-1218.

Syvertsen, J.P. 1981. Hydraulic conductivity of four commercial citrus rootstocks. J. Amer. Soc. Hort. Sci. 106:378-381.

Syvertsen, J.P. and J.H. Graham. 1985. Hydraulic conductivity of roots, mineral nutrition, and leaf gas exchange of citrus rootstocks. J. Amer. Soc. Hort. Sci. 110:865-869.

Taylor, H.M. and B. Klepper. 1975. Water uptake by cotton root systems: An examination of the assumptions in the single root model. Soil Sci. 120:57-67. 